Рязанцев Никита Валерьевич, ассистент кафедры «3aщита растений и плодоовощеводство», Саратовский государственный аграрный университет имени Н.И. Вавилова. Россия.

Рябушкин Юрий Борисович, $\partial-p$ c.- $x$. наук, проф. кафедры «Защита растений и плодоовощеводство», Саратовский государственный аграрный университет имени Н.И. Вавилова. Россия.

Еськов Иван Дмитриевич, $\partial-p$ c.- $x$. наук, проф., зав. кафедрой «Защита растений и плодоовощеводство», Саратовский государственный аграрный университет имени Н.И. Вавилова. Россия.
410012, г. Саратов, Театральная пл., 1.

Тел.: (8452) 26-16-28.

Морозова Светлана Владимировна, канд. геогр. наук, доцент кафедры «Метеорология и климатология», Саратовский государственный научный исследовательский университет имени Н.Г. Чернышевского.

410012, г. Саратов, ул. Астраханская, 83.

Тел.: (8452) 26-16-96.

Ключевые слова: виноград; сорт; оидиум; макроскопическая диагностика; эпифитотия; устойчивость; толерантность.

\title{
EFFECT OF WEATHER CONDITIONS ON THE DEVELOPMENT OF GRAPE OIDIUM IN THE STEPPE ZONE OF THE LOWER VOLGA REGION
}

Ryazantsev Nikita Valeryevich, Assistant of the chair "Plant Protection and Horticulture", Saratov State Agrarian University named after N.I. Vavilov. Russia.

Ryabushkin Yuriy Borisovich, Doctor of Agricultural Sciences, Professor of the "Plant Protection and Horticulture", Saratov State Agrarian University named after N.I. Vavilov. Russia.

Eskov Ivan Dmitrievich, Doctor of Agricultural Sciences, Professor, Head of the chair "Plant Protection and Horticulture", Saratov State Agrarian University named after N.I. Vavilov. Russia.

Morozova Svetlana Vladimirovna, Candidate of Geographical Sciences, Associate Professor of the chair "Meteorology and Climatology", Saratov State University named after N.G. Chernyshevsky. Russia.

Keywords: grape; variety; oidium; macroscopic diagnostics; epiphytoty; resistance; tolerance.

The peculiarities of the oidium spread in the steppe zone of the Lower Volga re-gion were studied on 33 grape varieties taking into account the weather conditions of this region. It has been shown that two of seven years of research were charac-terized bv oidium epidhvtotics, two years - by the disease of medium severity, and three years - by the mild case. The most favorable weather conditions for the disease development are identified. A macroscopic study of oidium spread has shown that different varieties of grape have different resistance to the causative agent of the disease. The following groups of varieties were identified: unstable - Zhem-chug Saba, MadLen Anzhevin, Shasla belaya; medium resistant Aleshenkin, Bul-garia, Victoria, Ukrainka, Tsvetochniy; tolerant - Bianca; Kishmish Mirazh, Levokumsky ustoichivyi, Muscat letniy; highly resistant-Augustine, Arcadia, Vostorg, Vostorg Idealniy, Vostorg krasniy, Vostorg cherniy, GF 14-75, Kantemirovsky, Kobzar, Korinka Russkaya, Lucy Belaya, Pamyati Negrulya, European Pleven, Smuglyanka Moldavskaya, Talisman, Ezop; very highly resistant - Bako cherniy, Kishmish Hungarian, Lediya, Nectarniy, Severniy Plechistic. For industrial culti-vation in the steppe zone of the Lower Volga region, varieties characterized by in-creased oidium resistance are recommended.

удк 619:616-07

\section{ПОЛУЧЕНИЕ ВНЕКЛЕТОЧНОГО МАТРИКСА ИЗ ОРГАНОВ ЖИВОтнЫХ}

\author{
СТРУчков Николай Афанасьевич, Якутская государственная сельскохозяйственная академия \\ НИФОНТОВ Константин Револьевич, Якутская государственная сельскохозяйственная академия \\ СИдОРОВ Михаил Николаевич, Якутская государственная сельскохозяйственная академия \\ АЛЕКСЕЕВА Нюргина Илларионовна, Якутская государственная сельскохозяйственная академия
}

Описаны способы получения внеклеточного матрикса (ВКМ) из органов сельскохозяйственных животных. Методом гистологического анализа проверено качество полученного геля, порочка и пластины.

Введение. Изучение внеклеточного матрикса и его компонентов - одно из важных направлений в биохимии и клеточной биологии. Заместительная тканевая терапия развивалась на основе изучения процессов, происходящих при регенерации тканей и органов $[4,5]$. Во многих исследованиях показана особенность децеллюляризованного внеклеточного матрикса, полученного по различным технологиям из разных источников, способствовать хемотаксису, миграции и дифференцировке клеток, а также ремоделированию собственных тканей организма [10-12].

Использование матриксов связано с тем, что для успешного лечения клеткам необходим субстрат, на котором они могут закрепиться или в виде суспензии клеток в гелях, или в виде моно- или многослоя на каркасах. Матриксы должны обеспечивать поступление питательных веществ к клеткам и удаление продуктов жизнедеятельности, обладать нужными физико-механическими свойствами для поддержки целостности клеток и тканей в течение всего периода имплантации [7-9].

К преимуществам гелевых форм матриксов относится большая гидратированность материалов, которая позволяет питательным веществам, газам и отходам жизнедеятельности диффундировать по всему объему матрикса, хорошая биосовместимость, 
меньшая травматичность при внесении в место имплантации [2]. Некоторые авторы склоняются к использованию синтетических материалов, однако они обладают недостатками - не повторяют пространственную архитектонику, а также не способны сохранять и поддерживать биологическую активность [3].

Внеклеточный матрикс в основном получают из органов сельскохозяйственных животных и человека. Для децеллюляризации подвергаются все органы животного, но необходимо подбирать или подстраивать протоколы для определенного размера и вида органа.

Цель данной работы - получение и исследование ВКМ, а также апробация методики оценки его качества при перфузионной децеллюляризации целых органов.

Методика исследований. Для реализации поставленной цели были определены следующие основные задачи:

получение продукта на основе ВКМ из мочевого пузыря северного оленя; из сердца и мочевого пузыря свиньи;

получение экспериментального образца ВКМ.

Для исследования использовали органы северного оленя и свиньи из ООО «Хатасский свинокомплекс». Материалом для получения ВКМ в виде геля послужил мочевой пузырь северного оленя. Порошок на основе внеклеточного матрикса получали из сердца свиньи. Децеллюляризованный орган в виде пластины получали из мочевого пузыря свиньи.

Оценку качества ВКМ осуществляли с помощью гистологических исследований. Именно гистологический анализ позволяет удостовериться, полностью ли очищены клетки от ядра и клеточного содержимого. В первый день из полученных материалов изъяли образцы размером около 0,7-1,0 см, фиксировали в 10\%-м нейтральном забуференном формалине в течение суток [3, 4]. Затем образцы помещали в 75\%-й спирт от 2 ч до суток, потом в $96 \%$-й и в завершение в 100\%-й спирт. На второй день использовали хлороформ в течение суток.

На финальной стадии получения гистопроб использовали парафин, расплавленный с хлороформом, их хранили в течение нескольких часов в термостате при постоянной температуре $37{ }^{\circ} \mathrm{C}$; остывали при комнатной температуре. Полученные парафиновые кубики с гистопробами резали на микротоме на 5 мкм. Гистопрепараты окрашивали гематоксилином и эозином и рассматривали на электронном микроскопе.

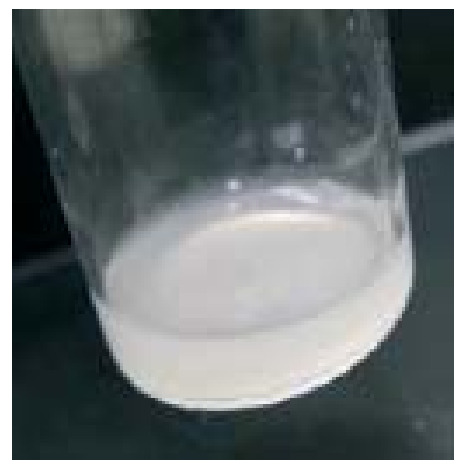

Рис. 1. ВКМ в виде геля
Результаты исследований. Получение ВКМ в виде геля из мочевого пузыря северного оленя. Мочевой пузырь хранили несколько месяцев в морозильнике при $-70{ }^{\circ} \mathrm{C}$ в специальном контейнере. После тщательной очистки полученный тонкий слой ткани из внутренней части пузыря несколько раз отмывали дистиллированной водой, а для дезинфекции применяли 70\%-й спирт. Затем помещали в сосуд с дистиллированной водой на 30 мин, автоматически смешивая с помощью шейкера. После орган помещали в раствор с $1 \times$ PBS, $1 \times \operatorname{SDS}$ и с антибиотиком $1 \%$ pen/ street на 24 ч. Антибиотик использовали для того, чтобы в органе не развивалась бактериальная микрофлора. После очистки в специальных растворах орган промывали дистиллированной водой в течение 5 ч. Исходные материалы ВКМ из мочевого пузыря помещали в морозильник при $-70^{\circ} \mathrm{C}$ на ночь.

Полученные материалы после заморозки перемещали в вакуум для лиофилизирования на 12-72 ч. После этого использовали растворы 0,01 N HCL и пепсин. Для получения 50 мл геля нам потребовалось около 50 мл 0,01 N HCL, 0,1 пепсина при 500 мг порошка из оленьего мочевого пузыря. Раствор оставляли при постоянном смешивании на магнитном смесителе в течение 24 ч и более [1].

В результате проведенной децеллюляризации мочевого пузыря оленя было получено серое желеобразное вещество, которое требовало тщательного хранения с соблюдением точной температуры (рис. 1).

Получение порошка на основе ВКМ из сердияа свиньи. От сердца отделяли жир и соединительные ткани, желудочки промывали водой от крови. Сердце было заморожено при $-70{ }^{\circ} \mathrm{C}$ в течение 16 ч для хранения и лизиса клеток. Затем его оттаивали в проточной воде при комнатной температуре. В аорту вставляли силиконовый шланг. После этого сердце помещали в химический стакан, содержащий 2 л дистиллированной воды, для рециркуляции с помощью перистальтического насоса в течение 15-20 мин. На следующем этапе заменяли дистиллированную воду на буферный раствор $2 \times$ PBS (фосфатный буферный раствор) - 10 мин 2 раза при скорости 700 мл/мин, т. е. 90 оборотов, после чего меняли буферный раствор на дистиллированную воду - 10 мин при скорости 750 мл/мин 95 оборотов.

На 2 л воды использовали 0,02\%-й трипсин (Tripsin) - 0,4 мг; 0,05\%-й EDTA - 3,3 мл; 0,05\%-й $\mathrm{NaN}^{3}$ (азид натрия) - 1 мг. Нагревали до $37{ }^{\circ} \mathrm{C}$ на водяной бане с перфузией через перистальтический насос в течение 3 ч, скорость которого меняли через каждый пройденный час. В первый час скорость подачи раствора была 1200 мл/мин (115 оборотов), во второй час - 1500 мл/ мин (150 оборотов), а в третий час 1800 мл/мин (165 оборотов). После этого сердце промывали дистиллированной водой в течение 10 минприскорости 1900 мл/ мин (180 оборотов). Затем промывали $2 \times$ PBS (фосфорным буферным раствором) в течение 10 мин при скорости 1950 мл/мин (195 оборотов). Для полной децеллюляризации провели перфузию: Triton X-100 в течение 2 ч при скорости подачи раствора 2000 мл/мин (200 оборотов), затем 
заменили на свежий Triton X-100 - 1,5 чпри скорости 2100 мл/мин (210 оборотов).

Сердце от не ионного моющего средства промывали в дистиллированной воде в течение 10 мин при скорости подачи воды через перфузионный насос 2150 мл/мин (215 оборотов). Затем промывали в буферном растворе $2 \times$ PBS в течение 10 мин при скорости 2150 мл/мин (215 оборотов). После этого использовали перфузию с $4 \% \mathrm{Na}$ Deoxcholate (деоксихолат натрия), на 2 л дистиллированной воды 80 г. Полученный раствор добавили в химический стакан с сердцем и проводили перфузию в течение 3 ч при скорости 2200 мл/мин - (220 оборотов). После каждого химического раствора использовали в качестве перфузата дистиллированную воду и буферный фосфорный раствор в течение 15 мин без рециркуляции и с последующей рециркуляцией для лизиса клеток и удаления клеточных и химических остатков.

Дезинфекция была достигнута путем перфузии 0,1\%-й надуксусной кислоты и 4\%-м этанолом в течение 1,5 ч при скорости 2200 мл/мин (220 оборотов). Кислоту нейтрализовали и удалили остатки из ВКМ путем перфузии с $1 \times$ PBS при скорости насоса 2200 мл/мин (220 оборотов) и дистиллированной водой 2 раза по 5 мин при скорости подачи раствоpa 2200 мл/мин (220 оборотов). Для подтверждения «чистоты» сердца от клеток брали пробы на ДНК, IHC, ГАГ - кусочки децеллюляризованного органа, замороженные при $-20{ }^{\circ} \mathrm{C}$. После сердце заморозили при $-70{ }^{\circ} \mathrm{C}$ на ночь и на следующий день лиофили-

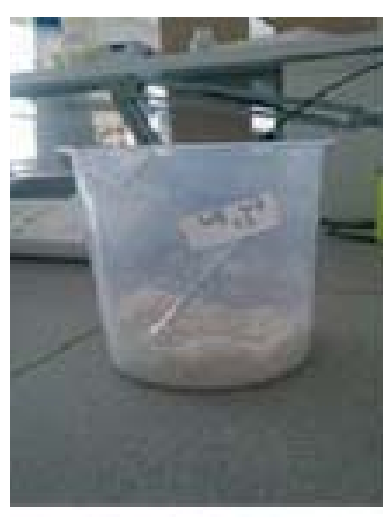

Рис. 2. Готовый порошок ВКМ из сердиа свиньи

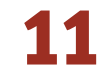
2018

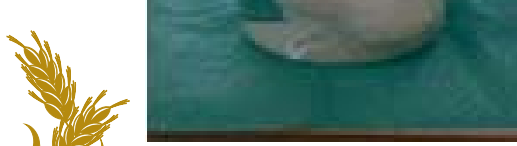

Рис. 3. Прощесс дещеллюляризащии зировали в вакууме в течение 3 дней, после чего измельчили в специальном аппарате (до порошка) c добавлением жидкого азота. После проведения лабораторных работ с сердцем свиньи был получен готовый порошок ВКМ (рис. 2). В начале работы сердце взвешивали, его масса составляла 425 г, после децеллюляризации 210 г, т.е. половину от исходной массы (рис. 3).

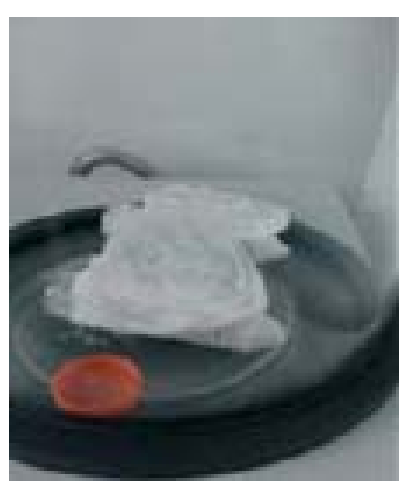

Рис. 4. Готовая пластина из мочевого пузыря свиньи
Получение пластины из мочевого пузыря свиньи. Тщательно отделили слои для получения тонкой ткани внутреннего слоя мочевого пузыря. Материал поместили в специальную емкость с дистиллированной водой на 1 ч, при постоянном смешивании с помощью шейкера. Процесс повторили 2-3 раза, дополнительно для дезинфекции применяли 70\%-й спирт в течение 5-10 мин.

После тщательной промывки материал поместили в растворы - $1 \times$ PBS 250 мл с 3\%-м Triton X-100 - 7 мл, антибиотиком 1\%-м pen/street 0,5 мл и дистиллированной водой - 250 мл на 24 ч при постоянном смешивании на шейкере. Чтобы очистить от остатка растворов, материал еще несколько раз промывали дистиллированной водой в течение нескольких часов $[1,2]$. Затем поместили на ночь в морозильник и выдерживали при $-70{ }^{\circ} \mathrm{C}$. Полностью замороженный материал помещали в вакуум для получения конечного продукта ВКМ. Таким образом получили децеллюляризированный орган из мочевого пузыря свиньи с изготовлением конечного продукта в виде пластины (рис. 4).

Заключение. Путем описанных способов мы получили продукт на основе ВКМ из мочевого пузыря северного оленя и из сердца и мочевого пузыря свиньи. Для подтверждения качества проведенных работ и оценки «чистоты» клеток от ядра и клеточного содержимого применяли специальное гистологическое исследование. Оно показало, что выведенный внеклеточный матрикс из свиного сердца и мочевого пузыря готов к использованию.

\section{СПИСОК ЛИТЕРАТУРЫ}

1. Волкова И.М., Коровина Д.Г. Трехмерные матриксы природного и синтетического происхождения для клеточной биотехнологии // Биотехнология. - 2015. - № 2. C. $8-26$.

2. Губарева Е.А., Сотниченко А.С., Гилевич И.В. Морфологическая оценка качества децеллюляризации сердца и диафрагмы крыс // Гены и клетки. - 2012. - № 4. - Т. 7. C. 20-27.

3. Иванов С.В., Иванов И.С., Должников А.А. Морфология тканей при использовании протезов из полипропилена и политетрафолена //Анналы хирургии. - 2009. № 3. - C. 59-64.

4. Николаева Е.Д. Биополимеры для клеточной и тканевой инженерии // Журнал Сибирского Федерального Университета. Серия: биология. - 2014. - № 2. - Т. 7. C. 222-233.

5. Носик А.Г., Воронкина И.В., Юдинщева Н.И. Сравнительный анализ ВКМ, синтезируемого фибробластами различного происхождения // Царскосельские чтения. 2012. - № 16. - С. 226-229.

6. Смоленцев С.Ю., Романюк В., Винницкий С. Гистологическая картина в паренхиматозных органах свиней и крупного рогатого скота при применении лечебно-профилактического иммуноглобулина // Вестник Марийского государственного университета. - 2013. № 11. - С. 13-16.

7. Сотниченко А.С., Губарева Е.А., Гилевич И.В. Децеллюляризированный матрикс сердца крысы как основа для создания тканеинженерного сердца // Гены и клетки. - 2013. - Т. 8. № 3. - C. 86-94.

8. Тканевые матрицы клапанов сердца: состо- 
яние проблемы и перспективы / П.П. Яблонский [и др.] // Вестник СПбГУ. - 2016. - № 11(2). С. $51-61$.

9. Черных А.В., Малеев Ю.В., Шевцов А.Н. К вопросу о получении внеклеточных матричных каркасов методом перфузионной децеллюляризации // Вестник новых медицинских технологий. - 2016. - № 3. C. $149-156$.

10. Badylak S.F., Gilbert T.W. An overview of tissue and whole organ decellularization processes // Biomaterials. 2011,Vol. 32, No. 12, pp. 3233-3243.

11. Badylak S.F., Freytes D.O., Gilbert T.W. Extracellular matrix as a biological scaffold material: structure and function // ActaBiomater, 2009, P. 25.

12. Badylak S.F., Taylor D., Uygun K. Decellularization and recellularization of three - dimensional matrix scaffolds // Whole - Organ tissue Engineering Annu Rev. Biomed., 2011, P. 20.

Стручков Николай Афанасьевич, канд. вет. наук, доцент кафедры «Внутренние незаразные болезни, фармакология и акушерство» имени профессора Г.П. Сердиева, Якутская государственная сельскохозяйственная академия. Россия.

Нифонтов Константин Револьевич, канд. вет. наук, доцент кафедры «Внутренние незаразные болезни, фармакология и акушерство» имени профессора Г.П. Сердиева, Якутская государственная сельскохозяйственная академия. Россия.

Сидоров Михаил Николаевич, канд. вет. наук, доиент кафедры «Ветеринарно-санитарная экспертиза и гигиена», Якутская государственная сельскохозяйственная академия. Россия.

Алексеева Нюргина Илларионовна, ассистент кафедры «Внутренние незаразные болезни, фармакология и акушерство» имени профессора Г.П. Сердиева, Якутская государственная сельскохозяйственная академия. Россия.

677077, г. Якутск, ул. Чайковского, 32/1.

Тел.: + 79148212703 .

ключевые слова: тканевая инженерия; внеклеточный матрикс; органы; биотехнология.

\title{
EXTRACELLULAR MATRIKS'S (ECM) RECEIVING FROM BODIES OF ANIMALS
}

Struchkov Nikolai Afanasyevich, Candidate of Veterinary Sciences, Associate Professor of the chair "Internal Non-communicable Diseases, Pharmacology and Ob-stetrics named after Prof. G.P. Serdtsev", Yakut State Agricultural Academy. Rus-sia.

Nifontov Konstantin Revolyevich, Candidate of Veterinary Sciences, Associate Professor of the chair "Internal Noncommunicable Diseases, Pharmacology and Obstetrics named after Prof. G.P. Serdtsev", Yakut State Agricultural Academy. Russia.

Sidorov Mikhail Nikolaevich, Candidate of Veterinary Sciences, Associate Professor of the chair "Veterinary-sanitary Examination and Hygiene”, Yakutsk State Agricultural Academy. Russia.
Alekseeva Nyurgina Illarionovna, Assistant of the chair "Internal Non-communicable Diseases, Pharmacology and $\mathrm{Ob}$ stetrics named after Prof. G.P. Serdtsev", Yakut State Agricultural Academy. Russia.

Keywords: tissue engineering; extracellular matrix; organs; biotechnology.

Methods for obtaining extracellular matrix from the organs of farm animals are described. The quality of the obtained powder and gel was checked by the method of histological analysis.

\section{ВЗАИМОСВЯЗЬ УРОВНЯ РАСЩЕПЛЯЕМОСТИ ПРОТЕИНА КОРМОВ С МОЛОЧНОЙ ПРОДУКТИВНОСТЬЮ}

\author{
ФАТТАХОВА Зилия Фидаилевна, ТатНИИСХ ФИЦ КазНЦ РАН \\ ШАРАФУТДИНОВ Газимзян Салимович, Казанский государственный аграрный университет \\ ШАКИРОВ Шамиль Касымович, ТатНИИСХ ФИЦ КазНЦ РАН
}

Один из подходов решения проблемы кормового протеина в молочном скотоводстве - повышение эффективности усвоения ингредиентов кормов в многокамерном желудке жвачных. Это возможно путем целенаправленного изменения этих процессов методом соответствующего подбора кормов со сбалансированным соотношением в них питательных веществ, а также применения специальных препаратов, обеспечивающих оптимизацию микробной ферментации корма. Были поставлены научно-хозяйственные опыты по изучению влияния регуляторов рубцового пищеварения «И-Сак 1026» и «Новатан 50», вводимых в рационы коров в период раздоя, на молочную продуктивность. Установлено, что применение данных препаратов привело к положительному сдвигу в регуляции соотношения уровня расщепляемого и нерасщепляемого протеина кормов в рационе и росту молочной продуктивности. Использование «И-Сак 1026» и «Новатан 50» увеличивает среднесуточные удои в пересчете на базисную жирность соответственно на 16,0 и 13,3 \% при одновременной оптимизации качественного состава молока. Также повышалась массовая доля жира и белка в молоке на 0,14 и 0,24\% в абсолютных величинах и на 0,13 и 0,05\% соответственно по сравнению с контролем. 